\title{
SUSTAINABILITY BONDS. AN INTERNATIONAL EVENT STUDY
}

\author{
Mihaela MOCANU (D) ${ }^{*}$, Laura-Gabriela CONSTANTIN², \\ Bogdan CERNAT-GRUICI ${ }^{2}$ \\ ${ }^{1}$ Faculty of Accounting and Management Information Systems, \\ The Bucharest University of Economic Studies, Bucharest, Romania \\ ${ }^{2}$ Faculty of International Business and Economics, \\ The Bucharest University of Economic Studies, Bucharest, Romania
}

Received 04 September 2020; accepted 21 June 2021

\begin{abstract}
Sustainability bonds enable capital-raising and investment for those projects that have both a positive impact on the environment and a positive social outcome. This study examines the stock market reaction to the announcement of sustainability bonds issuance. The present research is designed as follows: first, an event study that examines the market reaction and second, a highlight of drivers influencing this market reaction via a linear regression with cluster-robust standard errors. Overall, small and negative sample-wide reactions to sustainability bond issue announcements were found. Additionally, the study finds significant negative abnormal returns before the publication in June 2018 of The Sustainability Bond Guidelines by the International Capital Market Association. Specifically, the size of the bond issue, whether the bond is callable or not, the announcement of the issue as a single event in a day, the company's Return on Assets, the firm's social disclosure score, and the issuance of the bond prior or after June 2018 are statistically significant factors that influence the stock returns of issuers.
\end{abstract}

Keywords: sustainability bonds, sustainable development, international capital markets, sustainable finance, event study, financial analysis.

JEL Classification: M41, C83, L20.

\section{Introduction}

Climate change along with a large variety of societal risks, especially those induced by the current pandemic, is currently acknowledged as a chief concern world-wide. Sustainable finance emerged and developed in response to these challenges. It is recognized as a key means to direct capital toward funding various projects which target the attainment of environmental, social, and governance imperatives that organizations face nowadays. The surge in products related to sustainable finance has been motivated by the investors' quest

${ }^{\star}$ Corresponding author. E-mail: mihaela.g.mocanu@gmail.com

Copyright $\odot 2021$ The Author(s). Published by Vilnius Gediminas Technical University

This is an Open Access article distributed under the terms of the Creative Commons Attribution License (http://creativecommons. org/licenses/by/4.0/), which permits unrestricted use, distribution, and reproduction in any medium, provided the original author and source are credited. 
of balancing financial returns and wider social and environmental benefits (Wendt, 2020; La Torre \& Chiappini, 2020), as well as by the policy and regulation initiatives such as the 2030 Agenda for Sustainable Development or The Paris agreement (La Torre \& Chiappini, 2020; Gutterman, 2021).

Investors nowadays are increasingly concerned about environmental, social, and governance (ESG) issues. Many look beyond traditional financial products and therefore organizations world-wide are under pressure to show they operate responsibly. Dimson et al. (2020) expect an ESG revolution of the investment environment that will redesign asset management. The Global Sustainable Investment Alliance (GSIA) reports that investment products linked to ESG had a total value of USD 31 trillion at the beginning of 2018 (GSIA, 2019). Sustainability-themed investing and impact-on-community investing (investments heading for answering to social or environmental problems) experienced remarkable growth over the period 2016-2018 (GSIA, 2019). The United Nations Conference on Trade and Development [UNCTAD] (2020) observes the surge of sustainability-related financial products and stresses this upheave in social and sustainability bonds as part of the global efforts to overcome the COVID-19 pandemic.

In this context, this research focuses on sustainability bonds as defined by the International Capital Market Association [ICMA]. Sustainability bonds are loans used solely to finance a mixture of both social and green projects. The issuer classifies a certain bond as sustainability bond by considering its primary objectives for the underlying projects. Sustainability bonds should promote positive change in society and the environment (ICMA, 2018). Overall, such bonds could be considered more comprehensive since they allow the financing of a much broader range of projects than those that could generate only environmental benefits or only social benefits. From the perspective of an ESG-oriented investor, the appeal for this product may lie in the synergic effect of allotting funds toward projects that attain both environmental and socially-related outcomes. This is actually the distinct nature of sustainability bonds - the use of proceeds that concern projects with both a positive impact on the environment and a positive social outcome (AlAhbabi \& Nobanee, 2020; UNCTAD, 2020). While portraying the sustainable finance universe, Gutterman (2021) depicts the sustainability bonds as part of the wider family of sustainable bonds comprising also the green, the social and the sustainability-linked bonds. Unlike sustainability bonds, green bonds facilitate capital-raising for projects that bring benefits to the environment, while social bonds support projects that may have positive outcomes for members of society. Jones and Comfort (2020) underline the role of these three debt instruments delineating among their main distinct use of proceeds (projects aiming environmental results, projects that provide social benefits and a mix of projects that pursue both environmental and social outcomes). Currently, the pandemic leads to an increase in the interest for social causes, and therefore the social and sustainability bonds thrive (Tillier \& Schroeder, 2020).

A clear-cut praxis distinction among the three types of bonds (green, social and sustainability bonds) emerges from the taxonomies provided by some of the main exchanges, considered forerunners on the sustainable global debt capital markets. The London Stock Exchange [LSE] makes the certified use of proceeds a criterion for its "three separate, 
dedicated segments", the individual definitions being mentioned in the Sustainable Bond Market 2021 Factsheet (LSE, 2021). Following the same line of reasoning,

National Association of Securities Dealers Automated Quotations [NASDAQ] (2020) develops several bond segments within its Sustainable Debt Market, the issuances being aligned to the ICMA's principles and guidelines (the Green Bonds Principles, The Social Bonds Principles, the Sustainability Bond Guidelines, and the Sustainability Linked Bond Principles). For social and sustainability bonds, defining the target population stands as listing requirements among the use of proceeds criteria. As a pioneer in this field, the Luxembourg Stock Exchange developed The sustainable finance platform (The Luxembourg Green Exchange) where it publishes a well-defined classification of bonds (green bonds, social bonds, sustainability bonds, sustainability-linked bonds, Chinese domestic green bonds). This classification is endorsed by various internationally recognized standards, taxonomies, frameworks, and labels.

The European Investment Bank launched in 2007 the first green bond, called climate awareness bond and since then, the market for this asset class has grown significantly. Some researchers (e.g. Ferrer et al., 2021) argue that the green bond market is young and consequently the academic research on green bonds is rather limited and inconclusive. However, in the past few years, there is an abundance of papers devoted to the topic of green bonds (Quirici, 2020; Cheong \& Choi, 2020; Hammoudeh et al., 2020; Maltais \& Nykvist, 2020). There are two directions in investigating the implications of green bond financing. First, researchers examined the market pricing of green bonds and the impact of green bonds on market participants. Second, researchers were interested in whether issuing green bonds increases firm value on long term, despite the higher costs related to issuance (Cheong \& Choi, 2020). Dorfleitner et al. (2021) study the pricing of green bonds and emphasize the existence of a premium over conventional bonds. They also stress the importance of the second party opinion on the green shade, highlighting a positive association between this characteristic and the premium of the green bonds. Fatica et al. (2021) also stress the positive effect of an external review and of repeated transactions on the premium.

The market of sustainability bonds has also been developing - the volume of new issues tripled from 2018 to 2019 (DZ Bank, 2020). Thus, sustainability bonds become an increasing interest for both investors and academics. According to Lee (2020), investors are creating more demand for sustainability bonds, as they use as a benchmark the Sustainable Development Goals (SDG) index published by the United Nations Sustainable Development Solutions Network. The motivation researching sustainability bonds is the fact that these financial instruments are new and under-researched by comparison to green bonds.

A thorough literature review shows that no study investigated empirically the particular field of sustainability bonds. This research addresses this literature gap. It contributes to the academic literature in several ways: a comprehensive sample of sustainability bond issues from as many public sources as possible has been built; an event study has been carried out in relation to sustainability bonds announcements for the first time in the academic literature; variables both relevant and original are included in the analysis: the SDG index published by the United Nations Sustainable Development Solutions Network for the countries where each issuer is established; the three ESG scores published by Bloomberg for 
each issuer, and a dummy variable that reflects the issuance of the bond before or after the publication of The Sustainability Bond Guidelines by ICMA. Moreover, this research consists of a complex analysis including an event study, parametric and non-parametric tests, a linear regression with cluster-robust standard errors and numerous robustness checks.

This paper is structured as follows. First, it provides a through literature review. Second, it describes the methodology employed. The third section discusses the results, while the last part summarizes the authors' conclusions.

\section{Literature review}

The present study belongs to the pool of corporate finance studies that investigate how the stock market responds to the issuance of securities. Typically, this kind of studies find that the stock market responds negatively to equity issues, but shows no significant reaction to bond issues (Eckbo et al., 2007; Nayar \& Stock, 2008). More in-depth studies differentiate among convertible, exchangeable or callable bonds. The announcement of convertible bonds triggers a negative response (Rahim et al., 2014), while in the case of exchangeable bonds the results are mixed (Wang et al., 2019). The market reaction related to the callable feature of bonds is documented in the literature as follows: a non-significant reaction for callable bonds, a positive reaction for short maturity non-callable bonds, a negative reaction for long maturity non-callable bonds (Kish \& Livingston, 1993); a negative reaction which is significant only for the long-term unanticipated non-callable bonds (Kish, 1997); a significantly negative abnormal market reaction for the issuance of non-callable bonds and a positive one for callable bonds (Nayar \& Stock, 2008).

Compared to conventional bond announcements, the announcements of green bonds disclose two types of information: both a bond issuance and a signal of the firm's commitment to protecting the environment. Laborda and Sanchez-Guerra (2021) study the impact of green bonds announcements on the stock market and find a positive reaction. Similarly, the results of Zhou and Cui (2019) indicate that the announcements of green bond issuance have a positive effect on companies' stock prices. According to Flammer (2020), if it is found that the stock market reacts positively, this is most likely due to the interest of the issuing company for environmental matters. The same line of reasoning can be applied to this paper's specific topic - the market's reaction to the issuance of sustainability bonds. Many studies show that investors have a positive response to news about the issuance of green bonds (Wang et al., 2020; Tang \& Zhang, 2020; Roslen et al., 2017; Baulkaran, 2019). However, Lebelle et al. (2020) document a negative market reaction when announcing the issuance of green bonds, especially for first-time transactions and for those performed in developed markets. Other recent studies reflect the various interests of institutional investors when acquiring green bonds (Sangiorgi \& Schopohl, 2021), while some focus on low-and middle-income economies and highlight several barriers and recommendations for the expansion of the green markets in these countries (Ntsama et al., 2021). Jones and Comfort (2020) offer a perspective on green bonds and sustainability bonds in the retail sector. Zhan and Santos-Paulino (2021) stress the relevance of the sustainable bonds for the post COVID-19 pandemic recovery. 
Several papers employ an event study methodology to investigate issues related to corporate social responsibility (CSR). Examples of such papers are Karpoff et al. (2005), Becchetti et al. (2012), Fisher-Vanden and Thorburn (2011), Capelle-Blancard and Laguna (2010), Flammer (2013), Deng et al. (2013), or Aktas et al. (2011). The work of Krüger (2015) was cited by all researchers that chose an even-study methodology to investigate how the equity market reacts to the issuance of green bonds. However, the present paper is the first one to design an event study to detect the market's reaction to the announcement of issuing sustainability bonds. This methodology is employed because it is a staple instrument used to gauge the impact of selected events. In this regard, the Securities and Exchange Commission (SEC) uses regularly event studies (Bodie et al., 2018).

Many event-studies focus on the stock market's reaction to negative events. Karpoff et al. (2005) find that news about an environmental violation leads to stock value losses. The work of Capelle-Blancard and Laguna (2010) indicates that the stock market reacts negatively (and instantaneously) after explosions in chemical plants and refineries, while long-term evidence indicates that within six months, cumulative average abnormal returns (CAAR) remain negative and increase slightly in magnitude, although they are not significantly different from zero.

There are also event-studies that focus on the stock market's reaction to positive events. Basgoze et al. (2016) find that the companies listed in the Turkey Top 100 Brands list earn positive abnormal returns 7 months after the announcement. Becchetti et al. (2012) explore the stock price impact of inclusion in the Domini 400 Social Index and deletion from the same index. Fisher-Vanden and Thorburn (2011) select a sample of firms which announce their participation in one of the following voluntary environmentally-oriented programs: Ceres and the Environmental Protection Agency's Climate Leaders in the United States of America (EPA's CL). Results show noteworthy losses in the market value of companies that announce their joining of the Climate Leaders and subsequently when they announce their greenhouse gas emissions reduction goal. Krüger (2015) identifies a negative response, whereas the reaction is considerably weaker for the positive CSR events. Some event-studies focus on mergers and acquisitions such as Deng et al. (2013) and Aktas et al. (2011).

A line of reasoning relevant to this research is the signaling perspective taken into consideration by many researchers over the years (e.g. Jindřichovská et al., 2020; Roman et al., 2019; Mocanu, 2015; Busu, 2019; Iamandi, 2012). By issuing sustainability bonds, firms credibly signal their commitment toward the environment. Most studies have found that the equity market reacts positively to this signal (e.g. Flammer, 2013, 2020). As this commitment becomes a fact, firms' environmental performance increases, as well as their attractiveness in the eyes of those investors sensitive to environmental protection. Signaling that the company is concerned about sustainability issues has several benefits: it increases customer demand; it boosts sales and profit margins; it reduces the risk of future environmental liabilities and lawsuits; it cuts production costs due to pollution-reducing measures etc. as Fisher-Vanden and Thorburn (2011) emphasize. Moreover, enhanced environmental performance could stimulate the government to issue new regulations, which creates a competitive advantage for those companies that triggered the regulatory actions and complied first with them (Fisher-Vanden, \& Thorburn, 2011). Interesting is the approach 
of authorities in different countries. In fact, panel data is widely used in the literature on sustainability (Lapinskienè et al., 2017).

Some authors point out the fact that companies may engage in "green washing" with the sole purpose to strengthen their claims of sustainability and sustainable development (Gray, 2010). In the context of the present study, green washing designates the issuance of bonds labeled as "green" while their proceeds are actually used for purposes that have little environmental and social value (Larcker \& Watts, 2020). The same argument could be raised for sustainability bonds as well. Sustainability bonds may serve to finance projects that in reality have little or no impact on the environment and society. This behavior can be explained by the increasing external pressure to engage in sustainability matters. Flammer (2013) argues that companies chose to do what is most legitimized in their area and that they are incentivized by the changing institutional conditions) to engage in projects that protect the environment and/or benefit the society, besides bringing them financial returns. Though criticized as green washing, the willingness of businesses to implement sustainability-oriented initiatives is consistent with the institutional theory.

The subject of sustainable finance is also increasingly approached in academic works (Gutterman, 2021; La Torre \& Chiappini, 2020; Migliorelli, 2021; Sachs et al. 2016; Migliorelli \& Dessertine, 2019; Ziolo \& Sergi, 2019; Park, 2019; Wendt, 2018; Ramiah \& Gregoriou, 2016).

The concern of the financial industry professionals and international organizations for sustainable finance is highlighted by the variety of existent studies and initiatives. The World Federation of Exchanges (WFE) performs an Annual Sustainability Survey. In its latest edition, the $6^{\text {th }}$ one, WFE (2020) specifically emphasizes the interest of the exchanges in developing the segments for sustainability, social, and green bonds. Another project that stresses the importance of the subject for the professionals is the SSE Initiative (Sustainable Stock Exchanges Initiative - https://sseinitiative.org/about/) developed by well-known global organizations. Among various sustainable development and ESG related aspects, this global platform also provides guidance on green finance (https://sseinitiative.org/greenfinance/) and discloses through its database those exchanges that have sustainability bond listing segments (https://sseinitiative.org/exchanges-filter-search/). Also, in the field of the initiatives that support the objectives related to the UN SDG one can mention the Organisation for Economic Co-operation and Development [OECD] Centre on Green Finance and Investment (n.d.). A great contribution to the development of sustainable finance and sustainability bonds can be attributed to ICMA (https://www.icmagroup.org/sustainablefinance/) that developed guidance on the various sustainable finance instruments, including those in this analysis (https://www.icmagroup.org/sustainable-finance/the-principles/), as well as several initiatives (https://www.icmagroup.org/sustainable-finance/sustainable-finance-initiatives/). The Task Force on Climate-related Financial Disclosures [TCFD] (2017) considers these new financial assets as opportunities to advance the transition to a low emissions economy.

There are also international studies that reflect the importance of considering sustainability in their strategic decisions with value creating results (McKinsey, 2021) and even consider sustainable finance as a reflection of a new business model (Klynveld Peat Mar- 
wick Goerdeler [KPMG], 2020). Further, the pandemic context emphasized the importance of developing green and social oriented projects Ernst \& Young Global Limited [EYGM] (2021).

Overall, this research aims at providing insights regarding the effect of announcing sustainability bonds issuance on the wealth of shareholders. The present study starts from the following hypotheses:

$H_{1}$ : Stock prices react when companies announce the issuance of sustainability bonds.

Since a thorough literature review shows that there are no event studies regarding the market reaction to sustainability bond issuance, it is inferred that sustainability bonds will behave similarly to green bonds. As mentioned in the literature review section, there is mixed evidence related to the issuance of green bonds (statistically significant positive or negative reactions) but little evidence of non-statistically significant abnormality. In this regard, it is expected to observe, over the chosen event windows, actual returns that are statistically significant either higher or lower than returns that a forecasting model can reasonably predict.

The event study may yield three possible outcomes: non-significant CAAR which is an indication (but not necessarily proof) of market efficiency, statistically significant and positive CAAR which indicates a positive reaction of stock returns in the sense that investors valued the company more than normal (as a consequence to the issuance of sustainability bonds) and statistically significant and negative CAAR which is an indication that investors have a negative outlook on the issuer's performance, which materializes in lower than expected returns.

The cumulative average abnormal return (CAAR) during an "event window" was computed to capture the stock market reaction. CAAR is a measure of how much a stock price deviates from its expected value across an event window. Three event windows have been chosen, as follows: a 7 -day window $[-3 ;+3]$ as the main short run study; a 21-day window $[-10 ;+10]$ and 41 -day window $[-20 ;+20]$ for robustness. The common practice is to set the event date (i.e., day 0) as the day when the issuance of the sustainability bond has been announced. Many authors have chosen to employ an event study methodology in investigating bonds with the same approach (Flammer, 2013; Deng et al., 2013; Krüger, 2015; Wang et al., 2020; Tang \& Zhang, 2020).

$\mathrm{H}_{2}$ : Out of the three ESG elements, the social component discriminates most among the market responses in $S B$ issuances.

The novelty of the present research endeavor also consists in choosing the Bloomberg ESG Disclosure scores as independent variables. These scores reflect the transparency of the issuing company on the environmental, social and governance dimensions. The data captured by the ESG Disclosure Scores refer to key topics in the sustainability area, such as air quality; climate change; water and energy management; materials and waste; human capital; audit risk and oversight; compensation; diversity; board independence, structure and tenure; shareholders' rights. One expects that the most relevant among the three dimensions (environmental, social and governance) is the social dimension. The reason for this hypothesis is 
that the social dimension is what differentiates sustainability bonds from green bonds and could be more important to investors.

\section{$\mathrm{H}_{3}$ : The increasing standardization and transparency consolidate the SB market.}

There is a consensus regarding the importance of transparency for the success of a novel financial product. Wang and Zhi (2016) argued that an appropriate regulation framework and the state support can improve the mechanism of the green bond market, and could lead to better environmental protection. The same is valid for the new sustainability bonds. There is a lack of agreed-upon criteria for what makes a bond "sustainable". As long as it convinces investors it uses the funds for eco- and socio-friendly purposes, any company could issue a bond labeled as "sustainable". To bring more clarity to potential and actual investors, ICMA published in June 2018 The Sustainability Bond Guidelines, thus standardizing many aspects such as external reviews or impact reporting. One hypothesizes that after the publication of these guidelines, the market has a positive or neutral reaction to the issuance of sustainability bonds.

\section{Data and methodology}

The present research is designed on two levels: (1) the event study which examines the market reaction to the issuance of sustainability bonds and (2) the linear regression with cluster-robust standard errors which reveals the factors influencing this market reaction. This investigation is complemented with nonparametric tests of the potential drivers of the sustainability bonds issuances' effect. One employed Stata and SPSS Statistics for linear regressions, while for the event study (related robustness checks and statistical tests), one used the research app of Schimmer, Levchenko, and Müller (2014).

The sample was developed gradually, as follows. One applied the "use of proceeds" criterion to select corporate fixed income securities labeled as sustainable bonds in Bloomberg. The database was increased by screening the websites of exchanges with a sustainability bondlisting segment as indicated by the Sustainable Stock Exchanges initiative (https://sseinitiative.org/) and ICMA (https://www.icmagroup.org/). One thus identified 129 sustainability bond transactions, among which one selected those issued by companies that are currently listed and those with at least 120 trading days before the announcement date. The sample used in the event study encompassed 48 bonds issued by 27 companies listed on 15 stock exchanges. For the linear regression one accounted for missing data (4 events) and reduced the sample to 44 transactions.

\subsection{Event study}

In order to identify the short-term effects of sustainability bond issues, one employed a simple event study methodology. The main event study involves a sample-wide 7 days event window $[-3 ;+3]$ with a 120 -day estimation window. For the expected return model, one used a single factor market model with GARCH $(1,1)$ errors to determine forecasted returns $R_{i t}=\alpha_{i}+\beta_{i} \times R_{m t}+\varepsilon_{i t}$, which are subsequently subtracted from actual returns over the event window to determine "abnormal returns." Several parametric and non-parametric 
tests were performed to check the statistical significance of the "Average abnormal returns" - "AAR" and "Cumulative average abnormal returns" - "CAAR".

The robustness of the model's results was checked two-fold. First, for the same event window and estimation window, one employed a single factor CAPM (Capital Asset Pricing Model) market model to check the consistency of the results. This allowed the checking of the consistency of the CAARs and the robustness of the observations, overall. Second, the initial GARCH model was used, but the event window was increased to 21 and 41 days, respectively. This allowed observing whether the AARs are consistent within larger event windows.

In order to draw more meaningful conclusions, the data was grouped according to several criteria. First, the events were separated based on the number of announcements in one particular day. "Single" announcements were investigated, meaning that issuers would announce in a particular day a single upcoming issue versus "multiple" announcements, where issuers were making two or more announcements per day, irrespective of the bond's upcoming issue date. Second, a difference between issuers from the "financial" sector and issuers from "non-financial" industries was made, with the aim to uncover any biases that the market might have in this respect. It was expected that the reaction to financial issuers is less biased, resulting in lower or non-significant CAARs compared to non-financial issuers. Third, a separation between announcements "before" and "after" July 2018 was made. Since in June 2018 ICMA published The Sustainability Bond Guidelines (SBG), the expectation was that announcements regarding the issue of sustainability bonds starting with July 2018 exhibit more unbiased reactions compared to the period before the release of the guidelines. Lastly, a distinction between callable and non-callable sustainability bonds was made, a property of bonds proven to exhibit differentiating properties in other types of bonds. The aim was to observe whether sustainability bonds follow the pattern of other bond types making them this way more mainstream in the eyes of investors.

\subsection{Analysis of the drivers of the wealth effects}

For further insights, one analysed the drivers that influence the shareholders' wealth on announcing sustainability bond issues. These factors were chosen both to account for the variables employed in the mainstream literature, and to ensure an original approach. As in Hagendorff et al. (2013), one employs linear regression with cluster-robust standard errors. The model is $C A R[-3 ;+3]=\alpha+\beta^{\prime} S B F+\gamma^{\prime} C F+\delta^{\prime} E F+\varepsilon$ where:

- CAR $[-3 ;+3]$ - the cumulative abnormal returns determined for each issue over the $[-3 ;+3]$ time span around the announcement day;

- SBF - a vector of factors regarding the sustainable bond issue (the logarithm of the amount issued - AMISS_LOG, the maturity of the bond in years - TENOR, and two dummy variables reflecting if the bond is callable - CALLABLE, and if it was announced separately in one single day - SGEVD);

- $C F$ - a vector of factors associated with the issuer (the natural logarithm of the total net assets - TOTALASSET_LN, return on assets - ROA, and the Bloomberg ESG Disclosure scores as a reflection of the issuers' transparency on each of the three dimensions environmental - ENVDISC, social - SOCDISC, and governance - GOVDISC); 
- EF - a vector of factors associated with the business environment (the SDG index developed by Sustainable Development Solutions Network - SDSN and the Bertelsmann Stiftung as a proxy for the country's sustainable development status - SDGCOUNTRY2016, and two dummy variables: one reflecting the pertaining sector - financial or nonfinancial - SECTOR, and another one mirroring the bonds' announcement before or after the release of the sustainability bonds guidance by ICMA - AFTER_2018).

The financial factors were obtained from Bloomberg and Thomson Reuters Eikon for the fiscal year before the announcement of the issue. The SDG index was collected from the 2016 report (Sachs et al., 2016) from the website of The Sustainable Development Solutions Network - A global initiative for the United Nations and Bertelsmann Stiftung (https://www. sdgindex.org). The sector variable was determined by collapsing the various categories into two categories: financial and non-financial.

Table 1 provides the number of observations, the mean, the median and the standard deviation of all variables used in the main regression analysis grouped into three main categories: sustainable bond characteristics, issuing firm characteristics and business environment characteristics.

Table 1. Descriptive statistics (source: own design)

\begin{tabular}{|l|c|c|c|c|c|}
\hline \multicolumn{1}{|c|}{ Variable } & $\mathrm{N}$ & Mean & Median & Std. Dev. & Frequency of value 1 \\
\hline \multicolumn{5}{|c|}{ Sustainable bond characteristics } \\
\hline AMISS_LOG & 44 & 8.409 & 8.699 & 0.512 & \\
\hline TENOR & 44 & 7.886 & 6.000 & 5.812 & \\
\hline CALLABLE & 44 & 0.409 & 0.000 & 0.497 & $40.91 \%$ \\
\hline SGEVD & 44 & 0.250 & 0.000 & 0.438 & $25.00 \%$ \\
\hline \multicolumn{7}{|c|}{ Issuer characteristics } \\
\hline TOTALASSET_LN & 44 & 10.871 & 11.134 & 1.957 & \\
\hline ROA & 44 & 3.618 & 1.233 & 5.990 & \\
\hline ENVDISC & 44 & 31.779 & 36.967 & 15.728 & \\
\hline SOCDISC & 44 & 44.402 & 48.246 & 17.615 & \\
\hline GOVDISC & 44 & 56.778 & 57.143 & 7.785 & \\
\hline \multicolumn{7}{|c|}{ Business environment characteristics } & & \\
\hline GOVDISC & 44 & 71.791 & 73.616 & 6.907 & \\
\hline SDGCOUNTRY2016 & 44 & 0.523 & 1.000 & 0.505 & $52.27 \%$ \\
\hline SECTOR & 44 & 0.818 & 1.000 & 0.390 & $81.82 \%$ \\
\hline AFTER_2018
\end{tabular}

One applied initially multiple regression (OLS) on the 44 events sample and checked the assumptions, following Laerd Statistics (2015): (1) collective and individual linearity by analyzing, on one side, the scatterplot of the unstandardized predicted values and the studentized residuals and, on the other side, the partial regression plots; (2) homoscedasticity by using the same scatterplot of the unstandardized predicted values and the studentized 
residuals and relevant heteroskedasticity tests (the White's and the Breusch-Pagan tests); (3) absence of multicollinearity by analyzing the correlations tables and statistics (tolerance and VIF); and (4) presence of atypical points by analyzing outliers (examination of standardized and studentized residuals), leverage (examination of leverage values) and influential points (by looking at the Cook's Distance). One decided not to eliminate any observation as mild outlier behavior and risky but not dangerous leverage conduct, and no influential point were detected. One also checked for normality by performing the ShapiroWilk W test and also by analyzing the histogram of the standardized residuals and the normal Q-Q Plot of the studentized residuals and one confirmed a rather minor departure from normality. One addressed the mild issues regarding the assumptions as well as the cluster-based specificity of the sample (having many companies issuing multiple bonds) by introducing cluster-robust standard errors.

Empirical evidence suggests that in small samples such as this, the normal and chisquared distributions may provide poor approximations to the unknown distributions of the test statistics, therefore leading to anticonservative results. Therefore, one fitted a mixed model by using restricted maximum likelihood (REML), whereas the group variable is a unique identifier of each bond issuer. The denominator-degrees-of-freedom (DDF) adjustment Kenward-Roger was employed. The results are consistent with the ones in the final model. However, by comparison, linear regression is preferable.

Also, to establish the robustness of this research endeavor, one has re-run the final model by extracting a random sample representing $85 \%$ of the initial sample with the assistance of Stata. The results are consistent with the results of the model applied to 44 observations, which confirm the robustness of the results.

In addition, to describe the relationship at various points of CAR's conditional distribution, the study was supplemented with quantile regression. Applied were the Parente-Santos test for intra-cluster correlation (PSS) and Silva Machado-Santos Silva test for heteroskedasticity (MSS) to control for cluster correlation and to check whether robust standard errors are needed. Depending on the results, the approach accounts, if necessary, for cluster robust standard errors or heteroskedasticity-robust standard errors (Machado \& Santos Silva, 2000; Machado et al., 2011; Parente \& Santos Silva, 2016). Otherwise, quantile regression with robust errors or quantile regression was used. One estimated the regression for several quantiles, including the median one. If necessary, the standard errors were adjusted for 25 clusters in accordance with the various issuers in the sample.

For a more insightful view regarding the hypotheses, one also considered a univariate analysis. Thus, one applied the Somers' delta, a nonparametric measure, to ascertain the association between the individual drivers and the shareholders' wealth. For consistency, the test was applied with the option for clustered samples. The individual drivers were the AFTER2018 and SOCDISC - as proxies for enhanced transparency, and the CARs as a reflection of the market valuation outcomes. Both SOCDISC and CARs were transformed in quartile ordinal variables. The standard errors were adjusted for 25 clusters to account for the issuing companies. 


\section{Results}

\subsection{Results of the event study}

The short run event study $[-3 ;+3$ days] highlights some interesting aspects concerning the abnormality of returns, especially before the events. The cumulative average abnormal return for the 7-day period around the events is small and negative. This signifies a general pessimistic market reaction to the announcement of the issue of sustainability bonds. The statistical tests performed at the CAAR level, both parametric and non-parametric, seem to support the findings, although not exceptionally strongly. Two out of six parametric tests show that the result is statistically significant at $5 \%$ while $4 / 6$ show it's significant at $10 \%$. For the non-parametric tests, $2 / 4$ show significance at $10 \%$ (see Table 2). If one examines the significance of the average abnormal returns, one clearly sees that days " -3 " and " 1 " present small negative returns commonly associated with anticipative effects concerning the events under study. The statistical test below confirms this across the board. For all other AARs, the performed tests do not confirm the statistical significance.

Table 2. Results of the parametric and nonparametric tests for the 7-day event study (source: own design)

\begin{tabular}{|c|c|c|c|c|c|}
\hline \multicolumn{7}{|c|}{ CAAR Value $=-0,0061$} \\
\hline Patell & Csect & StdCSect & Adj. Patell & Adj. StdCSec & $\begin{array}{c}\text { Skewness } \\
\text { Corrected }\end{array}$ \\
\hline$-1.609^{*}$ & $-1.7429^{* *}$ & $-1.676^{\star *}$ & $-1.459^{*}$ & $-1.3714^{*}$ & $-1.8681^{* *}$ \\
\hline \multicolumn{7}{|c|}{ Nonparametric Tests } \\
\hline \multicolumn{7}{|c|}{ Gen. Rank T } & Gen. Rank Test Z & Gen. Sign Z \\
\hline \multicolumn{2}{|c|}{ Rank Z } & \multicolumn{7}{|c|}{$1.3456^{*}$} & $1.3456^{*}$ & -0.5525 \\
\hline
\end{tabular}

Note: ${ }^{\star}$ significant at $10 \% ;{ }^{* *}$ significant at $5 \% ;{ }^{* *}$ significant at $1 \%$.

When using a market model to forecast returns in the same event window, one observes that the initial results are consistent. CAAR is small and negative with $7 / 10$ statistical tests indicating significance at $5 \%$ or $10 \%$. With respect to average abnormal returns, one observes that the same event window days " -3 " and " -1 " present negative returns with strong statistical significance across all tests. Since the CAAR seems robust, the findings concerning the average short-term response to sustainability bonds emission announcements upon the market performance of issuers is relevantly negative. This is consistent with the recent findings of Lebelle et al. (2020) for green bonds and with those established in the mainstream literature for convertible bonds.

To confirm the relevance of the individual average abnormal returns, the event study for 21 and respectively 41 days was performed, trying to gather additional information concerning the long term-effects but, more importantly, to confirm that the short-term findings are present within a longer-term event window. The 21 days AARs show statistically significant and positive results in days " -8 ", " -5 " and " +10 ", negative for " +9 " and confirms the initial 
findings with negative AARs for " -3 ", " -1 ". Overall, the CAAR is negative but not statistically significant, however, at an AAR level, the consistency with the short-term event study is highlighted. Further increasing the event window, evidence is found that days " -20 ", " -16 ",

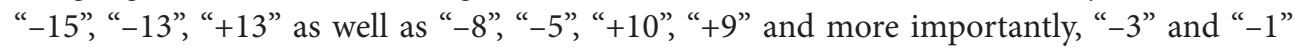
have statistically significant AARs across our tests. This confirms that the short-term results concerning AARs are robust, even when considering larger event windows.

To further prove the robustness of the results, it was shown that for two statistically significant AARs ( -3 and -1$)$ as well as the rest of the AARs over the event window, the ratio of positive to negative values is very similar across the different models and event windows. This shows the consistent abnormality identified at the level of returns, which enforces the anticipative nature of the market rather the reactive nature (see Table 3).

Table 3. Results of the robustness checks (source: own design)

\begin{tabular}{|l|c|c|c|c|c|c|c|}
\hline $\begin{array}{l}\text { EV window } \\
\text { size/ model }\end{array}$ & AAR(-3) & AAR(-2) & AAR(-1) & AAR(0) & AAR(1) & AAR(2) & AAR (3) \\
\hline $\begin{array}{l}7 \text { days/ } \\
\text { GARCH }\end{array}$ & $21: 27$ & $26: 22$ & $18: 30$ & $20: 28$ & $21: 27$ & $28: 20$ & $25: 23$ \\
\hline $\begin{array}{l}7 \text { days/ } \\
\text { MModel }\end{array}$ & $21: 27$ & $27: 21$ & $19: 29$ & $20: 28$ & $20: 28$ & $28: 20$ & $25: 23$ \\
\hline $\begin{array}{l}21 \text { days/ } \\
\text { GARCH }\end{array}$ & $20: 28$ & $25: 23$ & $17: 31$ & $19: 29$ & $23: 25$ & $28: 20$ & $25: 23$ \\
\hline $\begin{array}{l}21 \text { days/ } \\
\text { MModel }\end{array}$ & $20: 28$ & $27: 21$ & $17: 31$ & $19: 29$ & $25: 23$ & $28: 20$ & $26: 22$ \\
\hline
\end{tabular}

In addition to the event study across the sample, one shows the results of the grouping exercise. By looking if there is any difference between announcing multiple issues immediately, on the same day and announcing each bond issue separately, on different days, one can essentially gauge the effect of bundling announcements, irrespective of issue date. The results below show small and negative CAAR indicating an overall negative response to multiple announcements simultaneously, although the statistical tests do not confirm this aspect particularly strongly. Additionally, the parametric tests are not very reliable due to the small sample size. For single announcements, the CAAR is negative but not statistically significant (see Table 4).

The second grouping exercise yields more interesting results however (see Table 5). Before July 2018, there is strong evidence that the market had a negative reaction to sustainability bonds issue announcements. Across the board, especially the non-parametric tests, show very high statistical significance which highlights the large and negative market reaction. However, after the milestone, CAARs become statistically non-significant and a lot closer to zero. This is an indication that investors have a more unbiased approach to the events, which is a sign of increased transparency and market efficiency. Small and non-statistically significant CAARs were identified in the case of callable bonds. This is an indicator of market efficiency based on the 21 events sample. For the 27 events representing non-callable bonds, one found small and negative CAAR with some evidence of statistical significance based on the tests (Table 6). 
Table 4. Results of grouping the announcements by day (source: own design)

\begin{tabular}{|c|c|c|c|}
\hline \multicolumn{2}{|c|}{ Group } & Multiple & Single \\
\hline \multicolumn{2}{|l|}{ CAAR Value } & -0.011 & -0.004 \\
\hline \multirow{6}{*}{ Parametric Tests } & Patell & $-1.456^{*}$ & -10.081 \\
\hline & Csect & $-2.019^{* *}$ & -10.073 \\
\hline & StdCSect & $-2.22^{\star *}$ & -0.9022 \\
\hline & Adj. Patell & -1.145 & -1.009 \\
\hline & Adj. StdCSec & $-1.9035^{\star *}$ & -0.628 \\
\hline & Skewness Corrected & $-2.1077^{\star *}$ & -10.851 \\
\hline \multirow{4}{*}{ Nonparametric Tests } & Rank Z & $-1.4136^{*}$ & -0.629 \\
\hline & Gen. Rank T & $-1.576^{\star}$ & -0.4472 \\
\hline & Gen. Rank Test Z & $-1.921^{\star *}$ & -0.439 \\
\hline & Gen. Sign Z & -0.7215 & -0.2029 \\
\hline
\end{tabular}

Note: ${ }^{*}$ significant at $10 \%$; ${ }^{* *}$ significant at $5 \% ;{ }^{* *}$ significant at $1 \%$.

Table 5. Results of grouping the announcements by period (source: own design)

\begin{tabular}{|l|l|c|c|}
\hline \multicolumn{2}{|c|}{ Group } & After Jul 2018 & Before Jul 2018 \\
\hline \multicolumn{5}{|l|}{ CAAR Value } & -0.0034 & -0.0202 \\
\hline \multirow{5}{*}{ Parametric Tests } & Patell & -0.913 & $-1.928^{* *}$ \\
\cline { 2 - 4 } & Csect & -0.853 & $-4.637^{\star * *}$ \\
\cline { 2 - 4 } & StdCSect & -0.8243 & $-4.659^{* * *}$ \\
\cline { 2 - 4 } & Adj. Patell & -0.851 & $-1.912^{* *}$ \\
\cline { 2 - 4 } & Adj. StdCSec & -0.5652 & $-3.844^{* * *}$ \\
\cline { 2 - 4 } & Skewness Corrected & -0.9188 & $-5.542^{* * *}$ \\
\hline \multirow{5}{*}{ Nonparametric Tests } & Rank Z & -0.5183 & $-2.213^{* *}$ \\
\cline { 2 - 4 } & Gen. Rank T & -0.3019 & $-4.08^{* * *}$ \\
\cline { 2 - 4 } & Gen. Rank Test Z & -0.3309 & $-4.028^{* * *}$ \\
\cline { 2 - 4 } & Gen. Sign Z & 0.656 & $-2.834^{* * *}$ \\
\hline
\end{tabular}

Note: ${ }^{\star}$ significant at $10 \%$; ${ }^{* *}$ significant at $5 \%$; ${ }^{* *}$ significant at $1 \%$.

Table 6. Results of grouping the announcements by the callable feature (source: own design)

\begin{tabular}{|c|c|c|c|}
\hline \multicolumn{2}{|c|}{ Group } & Callable & Not Callable \\
\hline \multicolumn{2}{|l|}{ CAAR Value } & -0.003 & -0.0093 \\
\hline \multirow{6}{*}{ Parametric Tests } & Patell & -0.693 & $-1.718^{\star *}$ \\
\hline & Csect & -0.661 & $-1.766^{\star *}$ \\
\hline & StdCSect & -0.987 & $-1.544^{\star}$ \\
\hline & Adj. Patell & -0.706 & $-1.525^{\star}$ \\
\hline & Adj. StdCSec & -1.249 & -1.153 \\
\hline & Skewness Corrected & -0.627 & $-1.997^{\star \star}$ \\
\hline
\end{tabular}


End of Table 6

\begin{tabular}{|c|l|c|c|}
\hline \multicolumn{2}{|c|}{ Group } & Callable & Not Callable \\
\hline \multirow{4}{*}{ Nonparametric Tests } & Rank Z & -0.22 & $-1.642^{\star}$ \\
\cline { 2 - 4 } & Gen. Rank T & -0.961 & -1.011 \\
\cline { 2 - 4 } & Gen. Rank Test Z & -0.912 & -1.168 \\
\cline { 2 - 4 } & Gen. Sign Z & -0.287 & -0.664 \\
\hline
\end{tabular}

Note: ${ }^{\star}$ significant at $10 \% ;{ }^{* *}$ significant at $5 \% ;{ }^{* *}$ significant at $1 \%$.

The overall results (Table 2), grouping by single/multiple announcements per day (Table 4) and grouping by callability (Table 6) show negative CAARs which are between approx. $-1 \%$ and 0 . This implies that even though the market effects of the events are lower than normal, small and negative CAAR do not necessarily mean that investors perceive the events as failures, but as rather not fulfilling their potential. In contrast to the above, Table 5 shows large negative CAAR ( 2\%) for issuances before July 2018, which is a more clear-cut indication of non-performance, and non-statistically significant returns after July 2018 which represents a sign of market efficiency and normalisation. Table 6 shows that callable sustainability bonds present non-significant abnormal returns and statistically significant negative returns for non-callable bonds. These findings are consistent to what others such as Kish and Livingston (1993), Nayar and Stock (2008) and Kish (1997) find for conventional bonds.

Figure 1 shows in a clearer manner the results of the event study for the grouped events, differentiating between statistically significant and non-significant findings. Overall, it's
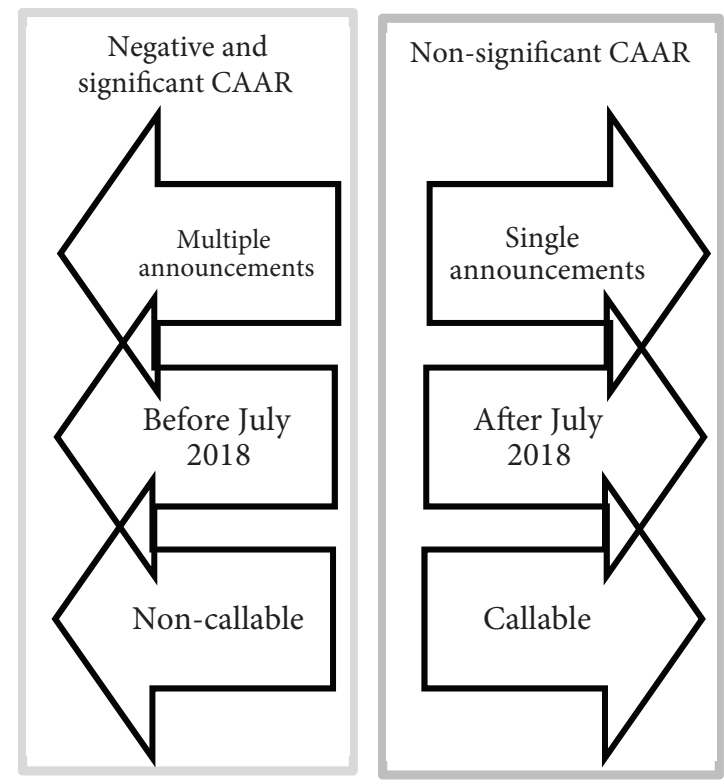

Figure 1. Event study results summary 
worth mentioning that the results of the event studies may be viewed in a vacuum in the sense that these only rely on the existence of the issuance of sustainability bonds. A more contextualized approach may be illustrated via a subsequent regression.

\subsection{The drivers of the wealth effects}

One hypothesized that the social disclosure score is of highest relevance compared to the governance and environmental disclosure scores when it comes to the market's response to sustainability bond issuances. Additionally, one suggests that a clear definition of sustainability bonds, the existence of specific guidelines and, in other words, a higher degree of standardization, impact positively the investors' reactions to announcements of sustainability bond issues. The milestone that one referred to is June 2018, the moment when ICMA published The Sustainability Bond Guidelines (SBG). The results of the linear regression indicate that these two hypotheses should not be accepted. As in Hagendorff et al. (2013), one computes cluster-robust standard errors and one treats each issuing firm as a cluster.

Table 7 presents the results of regressions on the announcement period returns $(\mathrm{CAR}[-3 ;+3])$. Model $(\mathrm{G})$ is the final model. The amount issued enters the model with a positive coefficient, which is significant at $1 \%$ (as found also by other studies such as Bachelet et al. 2019). Similarly, the financial performance of the issuer measured through "Return on Assets" enters the model with a positive and significant coefficient, as in the studies of Wang et al. (2020) and Flammer (2020).

It also shows that if the bond is callable, CARs decrease compared to the situation when the bond's issuance excludes such an option. The explanation might be that if the bond is callable, investors might think there is a risk that the environmental and social project is not brought to a good end. If the bond is issued after the publication in June 2018 of ICMA's Sustainability Bond Guidelines, CAR is higher compared to an issuance before June 2018 . Relevant appears to be also if the bond was announced together with other bonds on the same day by the same issuer or if there were announcements on different days for each bond. The cumulated abnormal returns decrease in case of multiple events in a day compared to single events in a day.

The Environmental Disclosure Score and the Governance Disclosure Score do not enter the model with a statistically significant coefficient (see Model (A)). This suggests that these components do not belong to the drivers of wealth effects when announcing the issue of sustainability bonds. The only disclosure score with an impact is the Social Disclosure Score, as initially hypothesized. The size of the issuer measured by total assets, the sustainable development status of the country where the issuer is based and the sector to which the issuer belongs do not enter the model (see the different models with different specifications as in Table 7).

As a robustness check, one extracted a random sample and re-ran the regression (see Model ( $\mathrm{H})$ ) according to the final Model (G). Additionally, one fitted a mixed model by using restricted maximum likelihood (REML), whereas the group variable is the unique identifier of each bond issuer (see Model (I)). The denominator-degrees-of-freedom (DDF) adjustment Kenward-Roger was employed. The results of both Model (H) and (I) are consistent with the ones in the final Model (G) (see Table 8). 


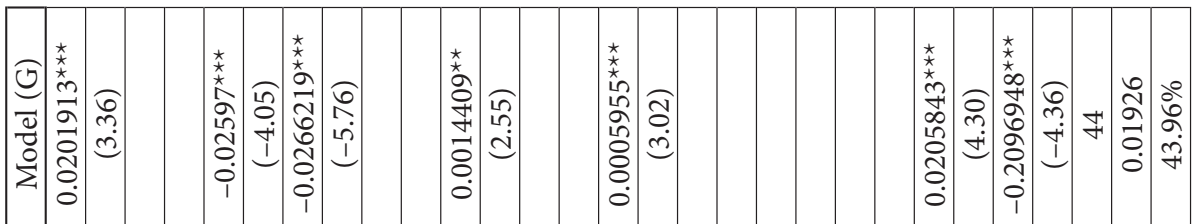

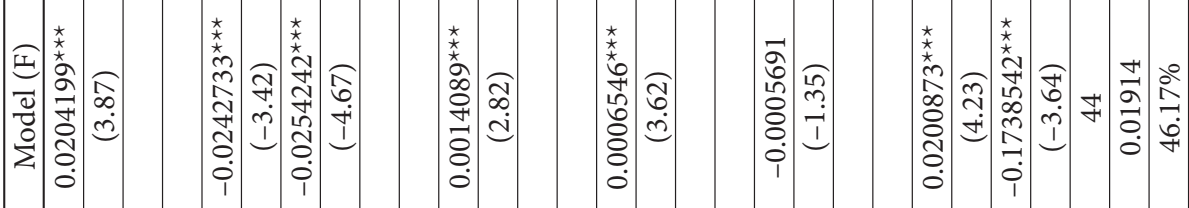

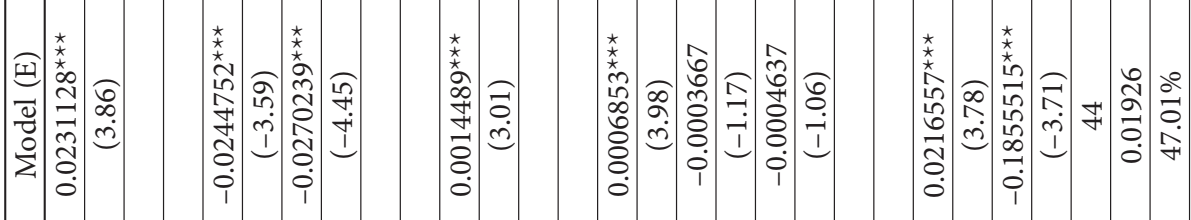

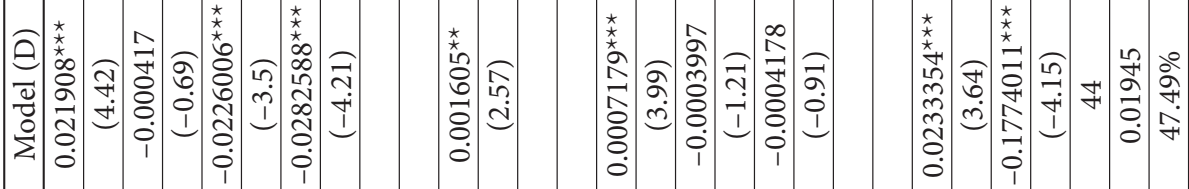

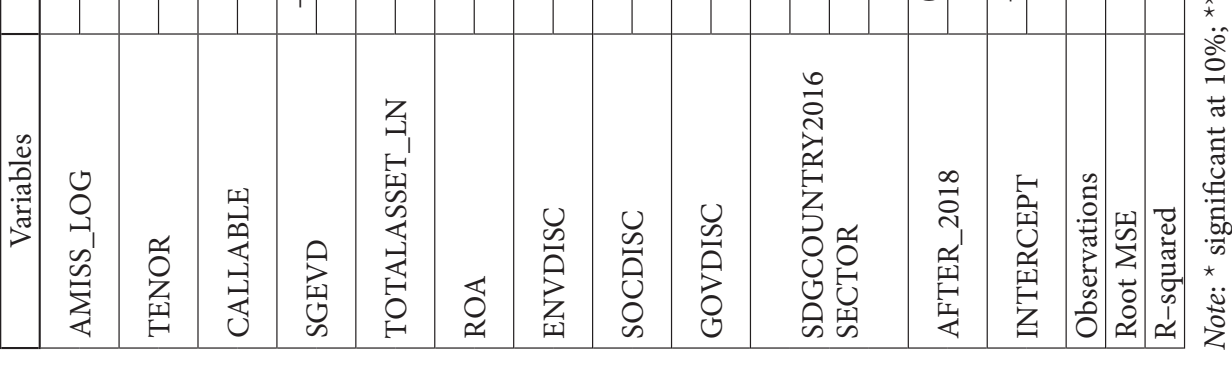


Table 8. Alternative regressions on abnormal issuer announcement returns (source: own design)

\begin{tabular}{|l|c|c|c|l|}
\hline \multicolumn{1}{|c|}{ Variables } & \multicolumn{2}{c|}{ Model $(\mathrm{H})$} & \multicolumn{2}{c|}{ Model (I) } \\
\hline AMISS_LOG & $0.0211176^{* * *}$ & $(3.27)$ & $0.0201913^{* * *}$ & $(3.04)$ \\
\hline CALLABLE & $-0.0252948^{* * *}$ & $(-3.31)$ & $-0.0259700^{* * *}$ & $(-3.08)$ \\
\hline SGEVD & $-0.0257195^{* * *}$ & $(-4.83)$ & $-0.0266219^{* * *}$ & $(-2.99)$ \\
\hline ROA & $0.0013103^{* *}$ & $(2.30)$ & $0.0014409^{* *}$ & $(2.34)$ \\
\hline SOCDISC & $0.0005054^{* *}$ & $(2.47)$ & $0.0005955^{* *}$ & $(2.55)$ \\
\hline AFTER_2018 & $0.0195458^{* * *}$ & $(3.51)$ & $0.0205843^{* *}$ & $(2.41)$ \\
\hline INTERCEPT & $-0.2134937^{* * *}$ & $(-4.12)$ & $-0.2096948^{* * *}$ & $(-3.76)$ \\
\hline Observations & \multicolumn{2}{|c|}{37} & & 44 \\
\hline Root MSE & \multicolumn{2}{|c|}{39.02104} & \\
\hline R-squared & \multicolumn{3}{c|}{} \\
\hline
\end{tabular}

Note: ${ }^{\star}$ significant at $10 \%$; ${ }^{* *}$ significant at $5 \%$; ${ }^{* *}$ significant at $1 \%$.

Another robustness check was to run quantile regressions, whose results are presented in Table 9. The coefficients are generally significant and consistent with those estimated when running linear regression with cluster robust standard errors described above.

Tables 10 and 11 present the results of the Somers' $d$ test between social transparency and stock market performance on one side, and the proxy for the market-enhanced transparency and the shareholders' wealth (Laerd Statistics, 2017). Both correlations are statistically significant and moderately positive.

Figure 2 highlights in a synthetic manner how wealth drivers are distributed according to their statistical significance and main characteristics considered within the regression.

\section{Conclusions}

The sample-wide short-term results point, on average, to small and negative stock valuation effects for the selected companies. It was found that, similarly to green bonds, sustainability bonds issuance could also signal a degree of insecurity concerning the profitability prospects. The negative reaction is not a standalone unequivocal evidence of poor, albeit small, market performance as a consequence of issuing sustainability bonds. On average, the findings seem to suggest that this reaction is anticipatory, being prevalent, especially in the days right before announcements. These results do not necessarily have any significance for current issuers given that a more in-depth analysis revealed that after July 2018, when ICMA published The Sustainability Bond Guidelines, cumulative average abnormal returns were not statistically significant, meaning that the market reaction was normalized. In this respect, the study did find strong significant and low abnormal returns before this date, which is an indication of its influence over the entire sample of events.

The results align with the literature for the general case of positive CSR events announcements, and for the case of sustainable bond issuances. As for the case of green bonds, the sustainability bond issues could also signal a certain degree of insecurity concerning the profitability prospects resulting from operational and capital outflows. 


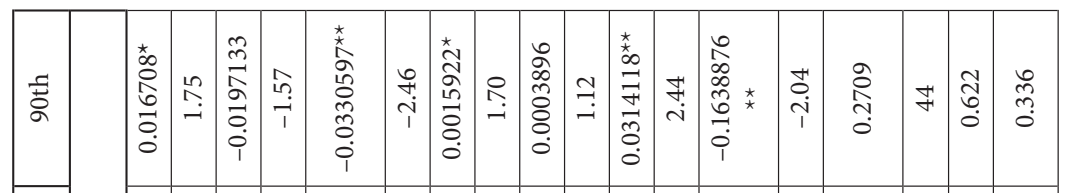

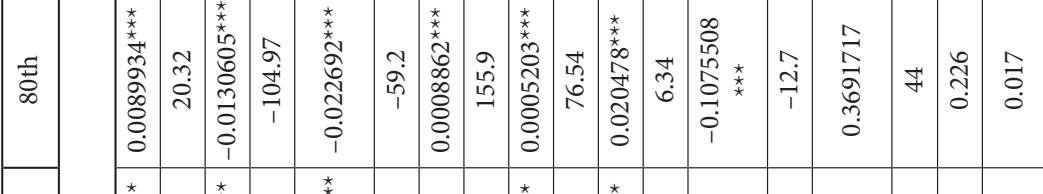

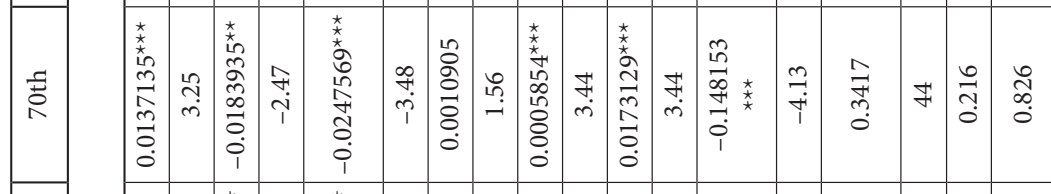

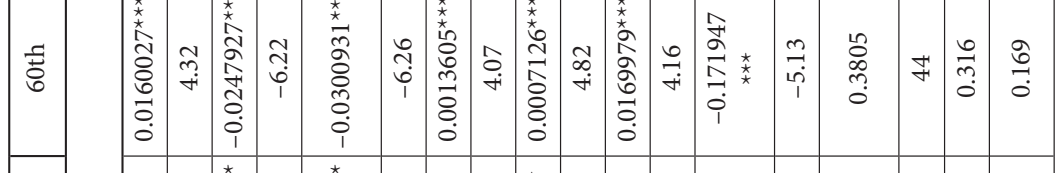

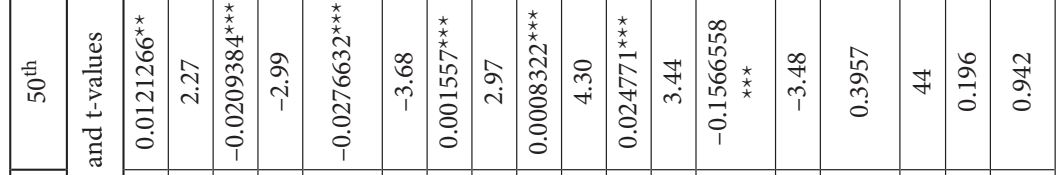

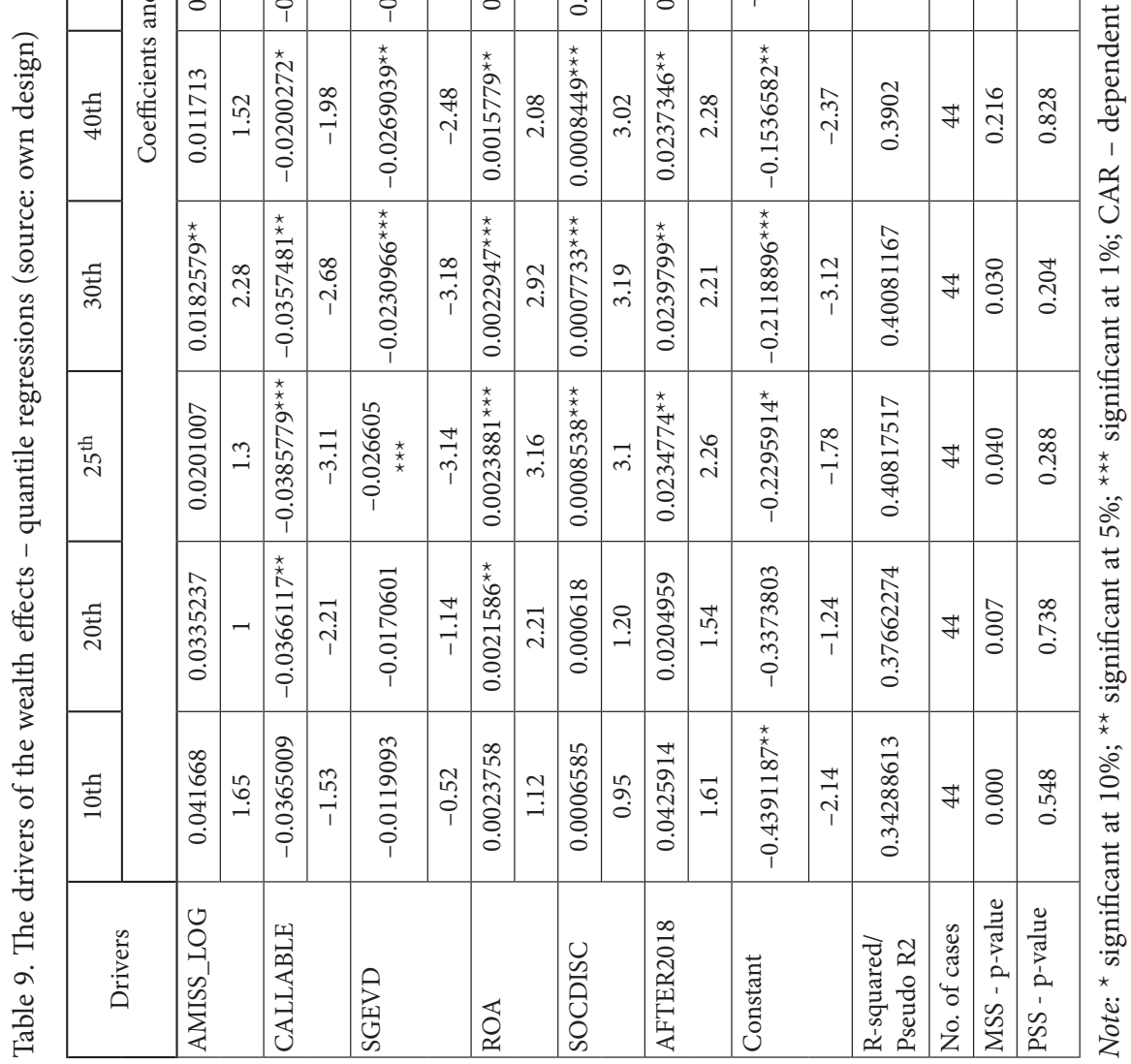


Table 10. Social transparency - shareholders' performance association (source: own design)

\begin{tabular}{|l|c|c|c|c|}
\hline Independent variable: NSOCIAL_4 & Coef. & Jackknife Std. Err. & $\mathrm{z}$ & $\mathrm{P}>\mathrm{z}$ \\
\hline Dependent variable: NCAR_4 & 0.299 & 0.141 & 2.12 & 0.034 \\
\hline
\end{tabular}

Table 11. Market enhanced transparency - shareholders' performance association (source: own design)

\begin{tabular}{|l|c|c|c|c|}
\hline Independent variable: AFTER_2018 & Coef. & Jackknife Std. Err. & $\mathrm{z}$ & $\mathrm{P}>\mathrm{z}$ \\
\hline Dependent variable: NCAR_4 & 0.500 & 0.178 & 2.81 & 0.005 \\
\hline
\end{tabular}

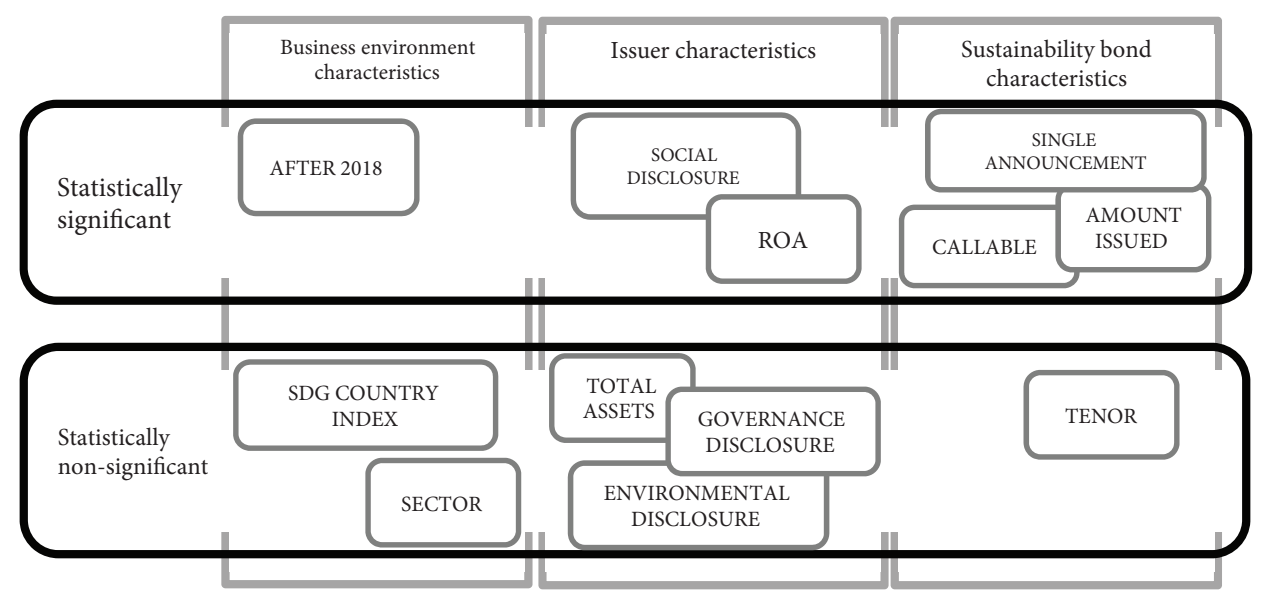

Figure 2. Drivers of wealth effects results summary

The stock markets' negative response to sustainability bonds issuance announcements is alleviated when the companies issue higher amounts, exhibit higher transparency on disclosing information about their social activities, and display higher profitability relative to its total assets. Further, the negative reaction is also relieved based on the moment of issuance (i.e., after the release of the sustainability bonds guide) reflecting the importance of regulations, guidance, or policies for expounding whether a certain product is sustainable.

These findings should be encouraging for issuers and investors, since it shows that the market currently retains a degree of fairness which is arguably more beneficial in certain instances than positive abnormal reactions. The implication of these results is farreaching in the sense that it provides some evidence that investors tend to appreciate the standardization suggested by the ICMA Guidelines, allowing the fundamentals to play a more prominent role than events. Sustainability bonds present a similar pattern compared to other types of bonds in the sense that non-callable sustainability bonds show small and negative CAARs but callable sustainability bonds show no signs of statistically significant abnormality. Evidence such as this can push sustainability bonds as an established instrument in the eyes of investors due to their similar expectation pattern compared to the bond general market. 
Looking at the issue in more detail, several characteristics related to the bond, the issuing firms, and the market tend to exert distinct influences on the value effects linked to sustainability bonds issuance. Specifically, the size of the bond issue, whether the bond is callable or not, the announcement of the issue as a single event in a day, the company's Return on Assets, the firm's social disclosure score, and the issuance of the bond prior or after June 2018 are statistically significant factors. The univariate research also confirms the hypothesis that the social component makes a significant positive difference, and that these transparency practices truly contribute to shareholders' value creation. This evidence could offer investors a concrete set of factors that are worth evaluating and ranking within their investment strategy in sustainability bonds.

More in depth, the market reaction to the issuance of sustainability bonds seems to be alleviated for issuers with a more efficient management when employing the firm's total assets, for those implementing higher amount transactions and for companies that are better or more visible when disclosing their social behavior. This last result seems to ascertain that companies with a superior disclosure behavior on their social performances can attract more investors. While environmental and governance behaviors should also be scrutinized by investors, the results imply that the social ones might differentiate among these transactions which are mixed-cause (environmental and social). Moreover, it is plausible that this propensity will intensify as social causes are currently experiencing an upsurge. The research confirms that more efforts to standardize innovative products will enhance the desired transparency in implementing sustainability causes and further attract investors.

These conclusions provide relevant evidence for issuers that profitability and social disclosure scores are relevant indicators that drive the performance of issued sustainability bonds. This evidence should lead to a common management framework of both financial fundamentals and social performance prior to the issuance of sustainability bonds. As investors look favorably upon the aforementioned elements, it's also worth highlighting that even though environmental and governance disclosure scores are not significantly impacting sustainability bonds performance, these factors should be revisited at some point in the future as more data becomes available.

New trends in financial management stress the importance of considering social and environmental factors. The findings of this paper support these new business models by empirically proving that proper disclosure of social elements is directly impacting the performance of sustainability bonds.

Although this paper has an outlook on several wealth driver factors relevant for bonds (some bonds characteristics, some issuer characteristics, and some business environment characteristics), further research may be performed to expand the array of factors in these three categories. This would lead to a more exhaustive perspective on the performance of sustainability bonds which would help bridge the know-how gap between bonds, in general, and green bonds and sustainability bonds, in particular. Additionally, a further lateral expansion is possible as more types of characteristics become better represented in studies regarding green bonds. Potential new evidence regarding the performance of green bonds should be subsequently investigated in the context of sustainability bonds. 
The limitations of this paper reside in the limited research performed so far in the field of sustainability bonds. In this respect, the wealth drivers were selected as per the common practice used for the research of green bonds or bonds, in general. This tunnel vision approach might ignore some wealth factors that are relevant specifically for sustainability bonds but not for any other kind of bonds. An interesting future perspective for this research is to monitor whether or not the considered characteristics will maintain their statistical significance in time (some characteristics may become statistically significant while other might lose this property) and investigate the drift/ convergence of sustainability bonds compared to green bonds (or other types of bonds, like the social or sustainabilitylinked bonds.) but also start looking at sustainability as a standalone instrument using the present research as a ground level.

\section{Author contributions}

The authors conceived the study and were responsible for the design of the methodology, for data collection and interpretation.

\section{Disclosure statement}

The authors declare no conflict of interest.

\section{References}

Aktas, N., DeBodt, E., \& Cousin, J. (2011). Do financial markets care about SRI? Evidence from mergers and acquisitions. Journal of Banking \& Finance, 35(7), 1753-1761. https://doi.org/10.1016/j.jbankfin.2010.12.006

AlAhbabi, R., \& Nobanee, H. (2020). Sustainability bonds: A mini-review. https://doi.org/10.2139/ssrn.3540119

Bachelet, M. J., Becchetti, L., \& Manfredonia, S. (2019). The green bonds premium puzzle: The role of issuer characteristics and third-party verification. Sustainability, 11(4), 1098. https://doi.org/10.3390/su11041098

Basgoze, P., Yildiz, Y., \& Metin Camgoz, S. (2016). Effect of brand value announcements on stock returns: empirical evidence from Turkey. Journal of Business Economics and Management, 17(6), 1252-1269. https://doi.org/10.3846/16111699.2016.1153517

Baulkaran, V. (2019). Stock market reaction to green bond issuance. Journal of Asset Management, 20(5), 331-340. https://doi.org/10.1057/s41260-018-00105-1

Becchetti, L., Ciciretti, R., Hasan, I., \& Kobeissi, N. (2012). Corporate social responsibility and shareholder's value. Journal of Business Research, 65(11), 1628-1635.

https://doi.org/10.1016/j.jbusres.2011.10.022

Bodie, Z., Kane, A., \& Marcus A. J. (2018). Investments (1 $1^{\text {th }}$ ed.). McGraw-Hill Education.

Busu, M. (2019). Assessment of the impact of bioenergy on sustainable economic development. Energies, 12(4), 578. https://doi.org/10.3390/en12040578

Capelle-Blancard, G., \& Laguna, M. (2010). How does the stock market respond to chemical disasters? Journal of Environmental Economics and Management, 59(2), 192-205.

https://doi.org/10.1016/j.jeem.2009.11.002 
Cheong, C., \& Choi, J. (2020). Green bonds: A survey. Journal of Derivatives and Quantitative Studies, 28(4), 175-189. https://doi.org/10.1108/JDQS-09-2020-0024

Deng, X., Kang, J. K., \& Low, B. S. (2013). Corporate social responsibility and stakeholder value maximization: Evidence from mergers. Journal of Financial Economics, 110(1), 87-109. https://doi.org/10.1016/j.jfineco.2013.04.014

Dimson, E., Marsh, P., \& Staunton, M. (2020). Credit suisse global investment returns yearbook 2020 summary edition. Research Institute. Credit Suisse. Zurich. https://www.credit-suisse.com/about-us/ en/reports-research/studies-publications.html

Dorfleitner, G., Utz, S., \& Zhang, R. (2021). The pricing of green bonds: External reviews and the shades of green. Review of Managerial Science, 1-38. https://doi.org/10.1007/s11846-021-00458-9

DZ Bank. (2020). DZ BANK Spotlight: Sustainable Bond market forecast 2020. Sustainable Finance Bulletin, 03. https://www.dzbank.de/content/dam/dzbank_de/de/home/produkte_services/institutionelle/bilder/Retarus/PDF/Archiv/DZB\%20Bulletin\%20Sustainable\%20Finance\%2003\%20E.pdf

Eckbo, E. B., Masulis, R. W., \& Norli, O. (2007). Security offerings. In B. E. Eckbo (Ed.), Handbook of empirical corporate finance: Handbooks in finance (Vol. 1, pp. 233-373). Elsevier/North-Holland. https://doi.org/10.1016/B978-0-444-53265-7.50020-2

Ernst \& Young Global Limited. (2021). Perspectives on a European green recovery from the COVID-19 pandemic (Summary report. April 2021). https://assets.ey.com/content/dam/ey-sites/ey-com/en_gl/ topics/assurance/assurance-pdfs/ey-green-recovery-report.pdf

Fatica, S., Panzica, R., \& Rancan, M. (2021). The pricing of green bonds: are financial institutions special? Journal of Financial Stability, 54, 100873. https://doi.org/10.1016/j.jfs.2021.100873

Ferrer, R., Shahzad, S. J. H., \& Soriano, P. (2021). Are green bonds a different asset class? Evidence from time-frequency connectedness analysis. Journal of Cleaner Production, 292, 1-23. https://doi.org/10.1016/j.jclepro.2021.125988

Fisher-Vanden, K., \& Thorburn, K. (2011). Voluntary corporate environmental initiatives and shareholder wealth. Journal of Environmental Economics and Management, 62(3), 430-445. https://doi.org/10.1016/j.jeem.2011.04.003

Flammer, C. (2013). Corporate social responsibility and shareholder reaction: The environmental awareness of investors. Academy of Management Journal, 56(3), 758-781. https://doi.org/10.5465/amj.2011.0744

Flammer, C. (2020). Corporate green bonds. Journal of Financial Economics (JFE) (in Press). https://doi.org/10.1016/j.jfineco.2021.01.010

Gray, R. (2010). Is accounting for sustainability actually accounting for sustainability... and how would we know? An exploration of narratives of organisations and the planet. Accounting, Organizations and Society, 35(1), 47-62. https://doi.org/10.1016/j.aos.2009.04.006

Global Sustainable Investment Alliance. (2019). Global sustainable investment review 2018. http://www.gsi-alliance.org/wp-content/uploads/2019/06/GSIR_Review2018F.pdf

Gutterman, A. S. (2021). Sustainable finance and impact investing. Business Expert Press. https://www.businessexpertpress.com/books/sustainable-finance-and-impact-investing/

Hagendorff, B., Hagendorff, J., \& Keasey, K. (2013). The shareholder wealth effects of insurance securitization: Preliminary evidence from the catastrophe bond market. Journal of Financial Services Research, 44(3), 281-301. https://doi.org/10.1007/s10693-012-0147-x

Hammoudeh, S., Ajmi, A. N., \& Mokni, K. (2020). Relationship between green bonds and financial and environmental variables: A novel time-varying causality. Energy Economics, 92, 1-8. https://doi.org/10.1016/j.eneco.2020.104941

Iamandi, I. E. (2012). Empirical analysis on CSR communication in Romania: Transparency and participation. Romanian Economic Journal, 15(46), 25-50. http://www.rejournal.eu/sites/rejournal. versatech.ro/files/articole/2012-12-01/1991/iamandi.pdf 
International Capital Market Association. (2018). The sustainability bond guidelines June 2018. ICMA. https://www.icmagroup.org/assets/documents/Regulatory/Green-Bonds/Sustainability-BondsGuidelines-June-2018-270520.pdf

Jindřichovská, I., Kubíčková, D., \& Mocanu, M. (2020). Case study analysis of sustainability reporting of an agri-food giant. Sustainability, 12(11), 4491-4511. https://doi.org/10.3390/su12114491

Jones, P., \& Comfort, D. (2020). Sustainability bonds and green bonds in the retail sector. International Journal of Sales, Retailing and Marketing, 9(1), 37-43. http://eprints.glos.ac.uk/8193/1/8193-Jones\%282020\%29-Sustainability-Bonds-and-Green-Bonds-in-the-Retail-Sector.pdf

Karpoff, J., Lott Jr. J., \& Wehrly, E. (2005). The reputational penalties for environmental violations: Empirical evidence. The Journal of Law and Economics, 48(2), 653-675. https://doi.org/10.1086/430806

Kish, R. J. (1997). Does the market react to surprise issues of callable and noncallable debt? Journal of Financial and Strategic Decisions, 10(1), 27-38. https://www.researchgate.net/profile/Richard_Kish/ publication/237783442_DOES_THE_MARKET_REACT_TO_SURPRISE_ISSUES_OF_CALLABLE_AND_NONCALLABLE_DEBT/links/5423f6dc0cf238c6ea6e8039.pdf

Kish, R. J., \& Livingston, M. (1993). Market reactions to callable and noncallable debt issues. Journal of Applied Business Research (JABR), 9(4), 54-64. https://doi.org/10.19030/jabr.v9i4.5994

Klynveld Peat Marwick Goerdeler. (2020). Sustainable finance: It's decision time. From niche product to new business model. Part one of our Sustainable finance series. https://assets.kpmg/content/dam/ $\mathrm{kpmg} / \mathrm{lu} / \mathrm{pdf} /$ sustainable-finance-it-is-decision-time.pdf

Krüger, P. (2015). Corporate goodness and shareholder wealth. Journal of Financial Economics, 115(2), 304-329. https://doi.org/10.1016/j.jfineco.2014.09.008

Laborda, J., \& Sanchez-Guerra, Á. (2021). Green bond finance in Europe and the stock market reaction. Estudios de economía aplicada, 39(3), 5. https://doi.org/10.25115/eea.v39i3.4125

Laerd Statistics. (2015). Multiple regression using SPSS Statistics. Statistical tutorials and software guides. https://statistics.laerd.com/

Laerd Statistics. (2017). Somers'd using Stata. Statistical tutorials and software guides. https://statistics.laerd.com/

La Torre, M., \& Chiappini, H. (2020). Sustainable finance: Trends, opportunities and risks. In M. La Torre \& H. Chiappini (Ed.), Part of the Palgrave Studies in Impact Finance. Contemporary issues in sustainable finance (pp. 281-288). Palgrave Macmillan. https://doi.org/10.1007/978-3-030-40248-8_11

Lapinskienè, G., Peleckis, K., \& Nedelko, Z. (2017). Testing environmental Kuznets curve hypothesis: The role of enterprise's sustainability and other factors on GHG in European countries. Journal of Business Economics and Management, 18(1), 54-67. https://doi.org/10.3846/16111699.2016.1249401

Larcker, D. F., \& Watts, E. M. (2020). Where's the greenium? Journal of Accounting and Economics, 69(2-3), 101312. https://doi.org/10.1016/j.jacceco.2020.101312

Lebelle, M., Lajili Jarjir, S., \& Sassi, S. (2020). Corporate green bond issuances: An international evidence. Journal of Risk and Financial Management, 13(2), 25. https://doi.org/10.3390/jrfm13020025

Lee, J. W. (2020). Green finance and sustainable development goals: The case of China. The Journal of Asian Finance, Economics and Business, 7(7), 577-586. https://doi.org/10.13106/jafeb.2020.vol7.no7.577

London Stock Exchange. (2021, February). Sustainable Bond Market (SBM). Factsheet. https://www.lseg.com/sites/default/files/content/documents/LSEG\%20SBM\%20Factsheet\%20 \%28effective\%2019\%20February\%202021\%29_0.pdf

Machado, J. A., \& Santos Silva, J. M. C. (2000). Glejser's test revisited. Journal of Econometrics, 97(1), 189-202. https://doi.org/10.1016/S0304-4076(00)00016-6 
Machado, J. A., Parente, P., \& Santos Silva, J. (2011). QREG2: Stata module to perform quantile regression with robust and clustered standard errors. https://econpapers.repec.org/software/bocbocode/ s457369.htm

Maltais, A., \& Nykvist, B. (2020). Understanding the role of green bonds in advancing sustainability. Journal of Sustainable Finance \& Investment, 1-20. https://doi.org/10.1080/20430795.2020.1724864

McKinsey. (2021). How companies capture the value of sustainability: Survey findings. https://www.mckinsey.com/business-functions/sustainability/our-insights/how-companies-capturethe-value-of-sustainability-survey-findings

Migliorelli, M. (2021). What do we mean by sustainable finance? Assessing existing frameworks and policy risks. Sustainability, 13(2), 975. https://doi.org/10.3390/su13020975

Migliorelli, M., \& Dessertine, P. (Eds.). (2019). The rise of green finance in Europe. Opportunities and challenges for issuers, investors and marketplaces. In Palgrave Studies in Impact Finance. Migliorelli, M., \& Dessertine, P. From Transaction-Based to Mainstream Green Finance (pp. 153-174). Palgrave Macmillan. https://doi.org/10.1007/978-3-030-22510-0

Mocanu, M. (2015). Nachhaltigkeitscontrolling im Rahmen von Corporate Governance. Grundlegende Ansätze und Instrumente. ASE Publishing House. https://docplayer.org/19590550-Nachhaltigkeitscontrolling-im-rahmen-von-corporate-governance-grundlegende-ansaetze-und-instrumente. html

National Association of Securities Dealers Automated Quotations. (2020). Nasdaq sustainable bond criteria. European Market Services. https://www.nasdaq.com/docs/2020/10/14/Nasdaq-Sustainable-Bond-Criteria.pdf

Nayar, N. N., \& Stock, D. (2008). Make-whole call provisions: A case of "much ado about nothing"? Journal of Corporate Finance, 14(4), 387-404. https://doi.org/10.1016/j.jcorpfin.2008.04.006

Ntsama, U. Y. O., Yan, C., Nasiri, A., \& Mboungam, A. H. M. (2021). Green bonds issuance: Insights in low-and middle-income countries. International Journal of Corporate Social Responsibility, 6(2), 1-9. https://doi.org/10.1186/s40991-020-00056-0

OECD. (n.d.). Centre on green finance and investment. https://www.oecd.org/cgfi/about/

Parente, P. M. D. C., \& Santos Silva, J. M. C. (2016). Quantile regression with clustered data. Journal of Econometric Methods, 5(1), 1-15. https://doi.org/10.1515/jem-2014-0011

Park, S. (2019). Green bonds and beyond: Debt financing as a sustainability driver. In B. Sjåfjell \& C. Bruner (Eds.), The Cambridge handbook of corporate law, corporate governance and sustainability (pp. 596-610). Cambridge University Press. https://doi.org/10.1017/9781108658386.049

Quirici, M. C. (2020). The increasing importance of green bonds as instruments of impact investing: Towards a New European Standardisation. In Palgrave studies in impact finance. M. La Torre \& H. Chiappini, Contemporary issues in sustainable finance (pp. 177-203). Palgrave Macmillan, Cham. https://doi.org/10.1007/978-3-030-40248-8_8

Rahim, N. A., Goodacre, A., \& Veld, C. (2014). Wealth effects of convertible-bond and warrant-bond offerings: A meta-analysis. The European Journal of Finance, 20(4), 380-398. https://doi.org/10.1080/1351847X.2012.712920

Ramiah, V., \& Gregoriou, G. N. (Eds.). (2016). Handbook of environmental and sustainable finance. Academic Press, Elsevier. https://www.worldcat.org/title/handbook-of-environmental-and-sustainablefinance/oclc/927585803

Roman, A.-G., Mocanu, M., \& Hoinaru, R. (2019). Disclosure style and its determinants in integrated reports. Sustainability, 11(7), 1960-1976. https://doi.org/10.3390/su11071960

Roslen, S. N. M., Yee, L. S., \& Ibrahim, S. A. B. (2017). Green Bond and shareholders' wealth: A multicountry event study. International Journal of Globalisation and Small Business, 9(1), 61-69. https://doi.org/10.1504/IJGSB.2017.084701 
Sachs, J., Schmidt-Traub, G., Kroll, C., Durand-Delacre, D. \& Teksoz, K. (2016). SDG index and dashboards 2016 (Global report). Bertelsmann Stiftung and Sustainable Development Solutions Network (SDSN), New York. https://www.sdgindex.org/reports/sdg-index-and-dashboards-2016/

Sangiorgi, I., \& Schopohl, L. (2021). Why do institutional investors buy green bonds: Evidence from a survey of European asset managers. International Review of Financial Analysis, 75, 101738. https://doi.org/10.1016/j.irfa.2021.101738

Schimmer, M., Levchenko, A., \& Müller, S. (2014). Research Apps. St. Gallen. EventStudyTools. https://www.eventstudytools.com

Tang, D. Y., \& Zhang, Y. (2020). Do shareholders benefit from green bonds? Journal of Corporate Finance, 61, 101427. https://doi.org/10.1016/j.jcorpfin.2018.12.001

Task Force on Climate-related Financial Disclosures. (2017). Recommendations of the task force on climate-related financial disclosures (Final report). https://assets.bbhub.io/company/sites/60/2020/10/ FINAL-2017-TCFD-Report-11052018.pdf

Tillier, N., \& Schroeder, B. (2020, July 8). Green bonds fade while social bonds blaze. https://think.ing.com/articles/sustainable-finance-green-bonds-fade-social-bonds-flare/

United Nations Conference on Trade and Development. (2020). World Investment Report 2020: International production beyond the pandemic. UNCTAD.

https://unctad.org/system/files/official-document/wir2020_en.pdf

Wang, J., Chen, X., Li, X., Yu, J., \& Zhong, R. (2020). The market reaction to green bond issuance: Evidence from China. Pacific-Basin Finance Journal, 60, 101294. https://doi.org/10.1016/j.pacfin.2020.101294

Wang, L., Chen, L., \& Chen, J. (2019). Announcement effect and its determinants of exchangeable bonds. Finance Research Letters, 30, 76-82. https://doi.org/10.1016/j.frl.2019.04.015

Wang, Y., \& Zhi, Q. (2016). The role of green finance in environmental protection: Two aspects of market mechanism and policies. Energy Procedia, 104, 311-316. https://doi.org/10.1016/j.egypro.2016.12.053

Wendt, K. (Ed.). (2018). Positive impact investing: A sustainable bridge between strategy, innovation, change and learning. Springer. https://doi.org/10.1007/978-3-319-10118-7

Wendt, K. (2020). Social stock exchanges: Defining the research agenda. In Palgrave studies in impact finance. M. La Torre \& H. Chiappini (Eds.), Contemporary issues in sustainable finance (pp. 79-129). Palgrave Macmillan. https://doi.org/10.1007/978-3-030-40248-8_5

World Federation of Exchanges. (2020). Exchanges advancing the sustainable finance agenda (The WFE's $6^{\text {th }}$ Annual Sustainability Survey). WFE. https://www.world-exchanges.org/storage/app/media/ WFE\%20Annual\%20Sustainability\%20Survey\%202020\%20150720.pdf

Zhan, J. X., \& Santos-Paulino, A. U. (2021). Investing in the sustainable development goals: Mobilization, channeling, and impact. Journal of International Business Policy, 4(1), 166-183. https://doi.org/10.1057/s42214-020-00093-3

Zhou, X., \& Cui, Y. (2019). Green bonds, corporate performance, and corporate social responsibility. Sustainability, 11(23), 6881. https://doi.org/10.3390/su11236881

Ziolo, M., \& Sergi, B. S. (Eds.). (2019). Financing sustainable development: Key challenges and prospects. Palgrave Studies in Impact Finance. Springer. https://doi.org/10.1007/978-3-030-16522-2 